\title{
Public Debt and Growth in Times of Low Interest Rates
}

The discussion about low interest rates and appropriate debt rules gained renewed impetus after Olivier Blanchard's 2019 presidential address to the American Economic Association. Interest rates are persistently below growth rates in most advanced economies, including euro area sovereigns. Under these conditions, could an active use of fiscal policy lead to a more stable growth rate? What are the main impediments to a more active fiscal policy? How much leeway do the fiscal authorities in the euro area have to follow counter-cyclical fiscal policies aimed at providing some stimulus to the economy? With interest rates much below growth rates, should concerns about debt sustainability in Europe be put to rest? This Forum seeks answers to these questions by looking at the private wealth accumulated by the private sector, introducing a Golden Rule under which deficits would be permitted to finance public investment, examining the sustainability of government debt through a behavioural macroeconomic model that uses 'animal spirits' and analysing the case of Japan.

Low Interest Rates and Public Borrowing

Daniel Gros, Centre for European Policy Studies, Brussels, Belgium.

\section{Capital Abundance and Its Consequences for Trade Policy}

Carl Christian von Weizsäcker, Max Planck Institute for Research on Collective Goods, Bonn, Germany.

Fiscal Policy at the Zero Lower Bound

Ángel Ubide, Citadel LLC, Chicago, USA.

Time to Change Budgetary Priorities in the Eurozone

Paul De Grauwe, London School of Economics, UK.

Yuemei Ji, University College London, UK.

Japanese Economy: Two Lost Decades and How Many More?

Yoshiyasu Ono, Osaka University, Japan. 